\title{
Microvascular endothelial cells express a phosphatidylserine receptor: a functionally active receptor for phosphatidylserine- positive erythrocytes
}

\author{
Yamaja Setty \\ Thomas Jefferson University \\ Suhita Gayen Betal \\ Thomas Jefferson University
}

Follow this and additional works at: https://jdc.jefferson.edu/pedsfp

Part of the Bioethics and Medical Ethics Commons

Let us know how access to this document benefits you

\section{Recommended Citation}

Setty, Yamaja and Betal, Suhita Gayen, "Microvascular endothelial cells express a phosphatidylserine receptor: a functionally active receptor for phosphatidylserine-positive erythrocytes" (2007). Department of Pediatrics Faculty Papers. Paper 6.

https://jdc.jefferson.edu/pedsfp/6

This Article is brought to you for free and open access by the Jefferson Digital Commons. The Jefferson Digital Commons is a service of Thomas Jefferson University's Center for Teaching and Learning (CTL). The Commons is a showcase for Jefferson books and journals, peer-reviewed scholarly publications, unique historical collections from the University archives, and teaching tools. The Jefferson Digital Commons allows researchers and interested readers anywhere in the world to learn about and keep up to date with Jefferson scholarship. This article has been accepted for inclusion in Department of Pediatrics Faculty Papers by an authorized administrator of the Jefferson Digital Commons. For more information, please contact: JeffersonDigitalCommons@jefferson.edu. 


\title{
Microvascular endothelial cells express a phosphatidylserine receptor: a functionally active receptor for phosphatidylserine-positive erythrocytes
}

\author{
B. N. Yamaja Setty ${ }^{1}$ and Suhita Gayen Betal ${ }^{1}$ \\ ${ }^{1}$ Marian Anderson Comprehensive Sickle Cell Anemia Care and Research Center, Department of Pediatrics, Division of Research Hematology, Jefferson \\ Medical College, Thomas Jefferson University, Philadelphia, PA
}

Phosphatidylserine (PS)-positive erythrocytes adhere to endothelium and subendothelial matrix components. While thrombospondin mediates these interactions, it is unknown whether PSassociated erythrocyte-endothelial adhesion occurs in the absence of plasma ligands. Using ionophore-treated PSexpressing control HbAA erythrocytes, we demonstrate that PS-positive erythrocytes adhered to human lung microendothelial cells in the absence of plasma ligands, that this adhesion was enhanced following endothelial activation with IL$1 \alpha$, TNF- $\alpha$, LPS, hypoxia, and heme, and that this adhesive interaction was selective to erythrocyte PS. We next explored whether microendothelial cells express an adhesion receptor that recognizes cell surface-expressed PS (PSR) similar to that expressed on activated macrophages. We demonstrate constitutive expression of both PSR mRNA and protein that were up-regulated in a time-dependent manner following endothelial activation. While minimal PSR expression was noted on unstimulated cells, endothelial activation up-regulated PSR surface expression. In antibody-blocking studies, using PSpositive erythrocytes generated either ar- tificially via ionophore treatment of control erythrocytes or from patients with sickle cell disease, we demonstrate that PSR was functional, supporting PSmediated erythrocyte adhesion to activated endothelium. Our results demonstrate the existence of a novel functional adhesion receptor for PS on the microendothelium that is up-regulated by such pathologically relevant agonists as hypoxia, cytokines, and heme. (Blood. 2008; 111:905-914)

() 2008 by The American Society of Hematology

\section{Introduction}

The anionic phospholipid phosphatidylserine (PS), present exclusively in the inner leaflet of the plasma membrane of a normal cell, is externalized following cell activation with both physiologic and pathologic stimuli such as activation of blood platelets resulting from vessel wall injury and cells that are undergoing apoptosis. ${ }^{1,2}$ PS exposure on the red cell surface occurs in patients with various hemolytic anemias ${ }^{3-9}$ activating numerous pathobiologic processes, of which one is red cell-endothelial cell adhesion. ${ }^{10,11}$ The mechanism(s) underlying this PS-mediated adhesion process is not well defined. Interaction of PS with immobilized subendothelial matrix thrombospondin has been documented. ${ }^{10}$ In addition, soluble thrombospondin-mediated adhesion of PS-positive erythrocytes to endothelium can occur via the constitutively expressed endothelial vitronectin receptor $(\mathrm{VnR}) .{ }^{10}$ Whether PS-related erythrocyte adhesion to endothelium can occur in the absence of plasma ligands is not known. In the present study, we explore this possibility, and hypothesize that endothelial cells express novel adhesion receptor(s) that can interact directly with PS-positive erythrocytes in the absence of plasma ligands. One such candidate is a receptor that recognizes cell surface-expressed membrane-associated phosphatidylserine, referred hitherto as the phosphatidylserine receptor or PSR, originally described by Fadok et al on the surface of activated macrophages that recognizes and phagocytoses PS-positive apoptotic cells. ${ }^{12}$ In the present study, we explore whether microvascular endothelial cells express this novel PS receptor. We demonstrate that both PSR transcript and protein are expressed in human microendothelial cells under basal conditions, and that expression is up-regulated following cell activation with various physiologic agonists. In further in vitro studies, we show that this receptor protein is externalized following endothelial cell activation, and that PSR is involved in PS-mediated erythrocyte adhesion to activated endothelium.

\section{Methods}

\section{Materials}

For enzyme-linked immunosorbent assay (ELISA), flow cytometric analyses, Western blots, and adhesion-blocking studies, monoclonal and polyclonal antibodies against human antigens and isotope-matched negative control antibodies were obtained from Cascade BioScience (Winchester, MA), Immunotec (Beckman-Coulter, Miami, FL), R\&D Systems (Minneapolis, MN), BD Biosciences (San Diego, CA), Chemicon International (Temecula, CA), Serotec (Oxford, United Kingdom), Bio-Rad Laboratories (Hercules, CA), Jackson ImmunoResearch Laboratories (West Grove, PA), or Sigma Chemical (St Louis, MO). These reagents included either pure or conjugated mouse monoclonal antibodies against PSR (clone 217), CD51 ( $\alpha$-chain of the vitronectin receptor, clone AMF7), CD106 (VCAM-1, clones 1G11, 51-10C9, and BBIG-V1), CD36 (the thrombospondin receptor, clone FA6.152), CD49d ( $\alpha$-chain of the VLA4, clone HP2.1), CD62P (P-selectin, clones CLB-Thromb/6, AK-6, and 9E1), CD54 (ICAM-1, clones $84 \mathrm{H} 10$ and BBIG-I1), CD47 (integrin-associated protein or IAP, clone BRIC126), CD239 (BCAM/LU, clone BRIC221), CD144
Submitted July 16, 2007; accepted September 17, 2007. Prepublished online as Blood First Edition paper, October 2, 2007; DOI 10.1182/blood-200707-099465.

The publication costs of this article were defrayed in part by page charge payment. Therefore, and solely to indicate this fact, this article is hereby marked "advertisement" in accordance with 18 USC section 1734. 
(cadherin-5, clone TEA1/31), CD146 (alternately known as MCAM, Muc-18, or S-endo, clone P1H12), $\beta$-tubulin (clone Tub2.1), isotypematched negative control antibodies (IgG isotype, clone 679.1Mc7, and IgM isotype), annexin-V-FITC, a rabbit polyclonal antibody against human PSR, horseradish peroxidase-conjugated goat anti-mouse IgG and antirabbit IgG, Cy-3-conjugated goat anti-mouse IgM, phycoerythrin (PE)- or fluorescein isothiocyanate (FITC)-conjugated goat anti-mouse IgG and anti-rabbit IgG, and alkaline phosphatase-conjugated goat anti-mouse IgG and IgM. While most experiments with anti-PSR have been done using the Cascade antibody, both the anti-PSR antibody produced by Henson and coworkers (Henson antibody; Fadok et $\mathrm{al}^{12}$ ) and the rabbit anti-PSR polyclonal antibody also were used in representative flow cytometry and adhesion experiments to compare and contrast the findings obtained with the Cascade antibody. Tumor necrosis factor- $\alpha$ (TNF- $\alpha)$, interleukin- $1 \alpha$ (IL-1 $\alpha$ ), the bacterial lipopolysaccharide (LPS), hemin, serine-L-phosphate, serine-D-phosphate, L- $\alpha$-phosphatidylserine (PS), L- $\alpha$-phosphatidylcholine (PC), the calcium ionophore A23187, and annexin-V (unconjugated pure, $33 \mathrm{kD}$; Sigma Chemical product no. A9460) were obtained from Sigma Chemical, R\&D Systems, or CN Biosciences (San Diego, CA). ${ }^{51} \mathrm{Cr}-$ Sodium chromate $(14.8-44.4 \mathrm{GBq} / \mathrm{mg})$ was obtained from PerkinElmer Life Sciences (Norton, OH). Tissue culture supplies were procured from Gibco Laboratories (Invitrogen, Carlsbad, CA) or Clonetics (Lonza, Walkersville, MD).

\section{Preparation of PS-positive erythrocytes}

For the majority of experiments, PS-positive HbAA erythrocytes were prepared from fresh blood drawn from adult control volunteers after informed consent was obtained in accordance with the Declaration of Helsinki. This study was reviewed and approved by the Institutional Review Committee for the protection of human subjects at Thomas Jefferson University. PS-positive red cells were prepared by treating these control erythrocytes with A23187 as previously described. ${ }^{3}$ In brief, washed erythrocytes (10\% hematocrit in buffer-A [10 mM HEPES in calcium- and magnesium-free Hanks balanced salt solution \{CMF-HBSS\}, pH 7.4] containing $2.5 \mathrm{mM} \mathrm{CaCl}_{2}$ ) were incubated for 1 hour with $2.5 \mu \mathrm{M} \mathrm{A} 23187$ and cells pelleted at $200 \mathrm{~g}$ for 10 minutes. Following one wash with $2.5 \mathrm{mM}$ EDTA and 2 washes with $1 \%$ BSA in buffer-A, the cell pellets were suspended in buffer-A to $50 \%$ hematocrit for labeling with ${ }^{51} \mathrm{Cr}$-sodium chromate, ${ }^{13}$ and also for evaluation of cell-surface PS and other adhesion markers by flow cytometry. ${ }^{14,15}$

\section{Culture of endothelial cells and HT1080 cells}

Human lung microvascular endothelial cells (HLMECs) were obtained from Clonetics and cultured according to the manufacturer's protocol. Cells at passages 2 to 4 were used. Representative experiments also were performed in human retinal capillary endothelial cells (HRCECs), which were isolated, identified, and cultured in minimal essential medium supplemented with $10 \%$ fetal calf serum. ${ }^{16}$ Cells from passages 6 to 8 were evaluated in the experiments to be described. As a positive control for both PSR antigen and mRNA analyses, we used HT1080 cells, a PSR-positive tumor cell line ${ }^{12}$ of epithelial origin derived from human fibrosarcoma (ATCC, Manassas, VA).

\section{Preparation of liposomes}

PC and PS liposomes were prepared as previously described. ${ }^{17}$ In brief, appropriate amounts of PC (PC liposomes) or PS and PC (50:50, for PS liposomes) were evaporated to semidryness, and reconstituted in buffer-A containing $1.25 \mathrm{mM} \mathrm{CaCl}_{2}$ to $10 \times$ in phospholipids. Following sonication for 3 minute, the lipid vesicles were diluted in desired assay medium, and extruded through a $1-\mu \mathrm{m}$ filter. The final concentration of total phospholipids in the assay medium was $30 \mu \mathrm{M}$, and was similar to levels previously used in adhesion experiments. ${ }^{11}$ These $1-\mu \mathrm{m}$ or smaller liposomes were nontoxic to both red cells and endothelial cells as judged by morphologic integrity and $\mathrm{LDH}$ release, and were stable for at least 24 hours at $37^{\circ} \mathrm{C}$ as tested by flow cytometry for PS positivity.

\section{Adhesion assays}

For adhesion assays, both PS-positive (A23187-treated) and PS-negative (untreated control) erythrocytes were labeled with ${ }^{51} \mathrm{Cr}$-sodium chromate, and suspended to $10 \%$ hematocrit in buffer-A containing $1.25 \mathrm{mM} \mathrm{CaCl}_{2}$ and $0.75 \mathrm{mM} \mathrm{MgCl}$ in the absence of plasma and plasma-associated soluble adhesion ligands. Radiolabeled erythrocytes containing 15\% PSpositive cells were evaluated for their adhesive potential ${ }^{18}$ using HLMECs. To assess direct interaction of PS with endothelial adhesion receptor(s), adhesion assays were conducted in the absence of plasma and soluble plasma ligands. To test whether endothelial activation modulated PSpositive erythrocyte adhesion, endothelial monolayers were subjected to treatment either with hypoxia for 24 hours $^{19}$ or with IL- $1 \alpha(10 \mathrm{ng} / \mathrm{mL})$, TNF- $\alpha(10 \mathrm{ng} / \mathrm{mL})$, or LPS (100 ng/mL) for 6 hours prior to adhesion. For blocking studies with liposomes or serine phosphate isomers, erythrocytes and endothelial cells were pretreated at $37^{\circ} \mathrm{C}$ for 45 minutes with the desired agent prior to adhesion. In experiments evaluating the role of specific endothelial adhesion receptors, endothelial monolayers were pretreated for 45 minute with $40 \mu \mathrm{g} / \mathrm{mL}$ of the appropriate monoclonal antibody prior to adhesion. PSR antibodies used in this study have been used extensively in studies assessing phagocytic recognition and removal of PS-expressing apoptotic cells by macrophages, fibroblasts, and epithelial cells. ${ }^{12,20,21}$ The rabbit polyclonal antibody against PSR from Sigma Chemical recognizes specifically the peptide sequence 363 to 381 of human PSR and has been shown to inhibit tethering of apoptotic Jurkat cells to human umbilical vein endothelial cells. ${ }^{22}$ Other antibodies used in our experiments have been previously shown to function as adhesion-blocking reagents. To test adhesion specificity of PS, PS-positive erythrocytes were incubated for 45 minutes in the presence or absence of annexin- $\mathrm{V}$ prior to adhesion. Concentrations of annexin- $\mathrm{V}$ for blocking studies were selected from preliminary dose-response experiments $(n=3)$ performed using PS-positive erythrocytes $\left(1 \times 10^{6}\right)$ and annexin- $\mathrm{V}(1-40 \mu \mathrm{g})$ with maximal cloaking (95\%-99\%) observed at $8 \mu \mathrm{g}$ annexin-V. In final confirmatory studies to assess the pathophysiologic relevance of PSR as a functional adhesion receptor for PS-positive red cells, we performed additional adhesion experiments using red cells from 9 individuals with HbSS disease, whose red cells by flow cytometry demonstrated either low or relatively high percentage of PS positivity (mean \pm SD: $1.0 \% \pm 0.8 \%$ vs $7.0 \% \pm 2.8 \%$, respectively). All adhesion experiments were assayed in triplicate with an intra-assay variability of less than $4 \%$.

\section{Analysis of endothelial PSR mRNA}

Steady-state PSR mRNA levels were evaluated using reverse-transcriptasepolymerase chain reaction (RT-PCR) analysis. Following incubation of endothelial cells for various times in the presence or absence of the desired agonist, total RNA was isolated using RNAqueous-4PCR kit (Ambion, Austin, TX), and $2 \mu \mathrm{g}$ total RNA was reverse transcribed using Superscript-II reverse transcriptase (InVitrogen). The RT product then was amplified using Taq DNA polymerase (Qiagen, Valencia, CA) and $0.8 \mu \mathrm{M}$ PSR-specific primers. The PSR primers included 5' -CCA-GAA-GTT-CAAGTG-TGG-TGA-GGA-3' (forward, nucleotides 403 through 426) and 5'-ACT-TTG-ATG-AGT-TCC-CTG-GGA-GTG-3' (reverse, nucleotides 774 through 751), which yielded a PCR-product of $372 \mathrm{bp}$. The transcript region selected for our RT-PCR analysis was similar to that previously described for PSR mRNA in brain and spleen from rat and mouse. ${ }^{23}$ cDNA for $\beta$-actin, a constitutively expressed transcript, was coamplified as an endogenous control for quantitation of PSR mRNA. The $\beta$-actin-specific primers $(0.0375 \mu \mathrm{M})$ used were $5^{\prime}$-ACG-TTG-CTA-TCC-AGG-CTG-TGCTAT-3' (forward, nucleotides 439 through 462) and 5' -ACT-CCT-GCT-TGCTGA-TCC-ACA-TCT-3' (reverse, nucleotides 1125 through 1102) yielding a PCR-product of $687 \mathrm{bp}$. Both PSR and $\beta$-actin primers were selected using the PrimerQuest Software (Integrated DNA Technologies, Coralville, IA) and custom synthesized by Invitrogen. PCR-products were resolved on a $1 \%$ agarose gel containing $0.4 \mu \mathrm{g} / \mathrm{mL}$ ethidium bromide and analyzed using a Bio-Rad Gel-Doc System. The relative ratio of test to endogenous was determined for each treatment, and expressed as a ratio. For sequence analysis, the amplified PCR fragment from the endothelial PSR transcript was purified using Qiagen Gel Extraction kit and sequenced on a ABI 
PRISM Model 3100 Genetic Analyzer (Applied Biosystems, Foster City, $\mathrm{CA}$ ), and the sequence was matched with published PSR mRNA.

\section{Analysis of endothelial PSR protein}

PSR protein levels in endothelial cells were evaluated using a variety of methods including Western blotting of total cellular proteins. Cell surface expression for PSR used 2 complementary methods, that is, flow cytometry-based (cell suspension) and fluorescence-based (intact cell monolayer) ELISA.

\section{Analysis of PSR protein by Western blotting}

Following incubation of endothelial cells for various times in the presence or absence of the desired agonist, total cellular proteins were extracted with Laemmli sample buffer. Total proteins $(20 \mu \mathrm{g})$ were denatured in sample buffer, resolved using $8 \%$ sodium dodecyl sulfate-polyacrylamide gel electrophoresis (SDS-PAGE), and transferred to nitrocellulose membranes. Membranes were blocked with $5 \%$ milk protein in phosphate-buffered saline containing $0.1 \%$ Tween-20, pH 7.4 (Tween-PBS), and probed sequentially with a rabbit polyclonal antibody against PSR (1:2000 dilution) and HRP-conjugated goat anti-rabbit $\operatorname{IgG}$ (1:10 000 dilution) diluted in Tween-PBS containing milk protein. After washing in TweenPBS, immunoreactive proteins were detected using a PerkinElmer ECL kit, images scanned, and protein bands quantitated. Membranes were stripped and reprobed for the constitutively expressed cytoskeletal protein $\beta$ tubulin, as an endogenous control (to correct for loading differences).

\section{Analysis of cell-surface expression of PSR protein by flow cytometry}

PSR protein expression on endothelial cells was evaluated by flow cytometry following exposure of monolayers to the desired agonist for 6 hours. Endothelial cells were harvested by incubating washed monolayers with $5 \mathrm{mM}$ EDTA in CMF-HBSS. One million cells (suspension in $100 \mu \mathrm{L}$ buffer-A containing $2.5 \mathrm{mM} \mathrm{CaCl}_{2}$ and $1 \% \mathrm{BSA}$ ) were incubated with anti-PSR $(2 \mu \mathrm{g})$ or an isotype-matched negative control antibody for 30 minutes, an additional 30 minutes with appropriate second antibody $(1 \mu \mathrm{g}$ Cy3-labeled goat anti-mouse IgM or FITC-labeled goat anti-rabbit $\mathrm{IgG})$ in the dark at room temperature, and analyzed in a FACScan Flow Cytometer (BD Immunocytometry Systems, San Jose, CA) at a flow rate of 200 to 500 cells/second. Data from 10000 events were collected and analyzed. Other endothelial adhesion receptors known to interact with red cells including VCAM-1, CD36, VnR, P-selectin, and ICAM-1 also were evaluated.

\section{Analysis of cell-surface expression of PSR protein by fluorescence ELISA}

PSR protein expression on intact HLMEC monolayers was evaluated using an ELISA-based assay similar to that previously described for other endothelial adhesion receptors. ${ }^{19}$ In brief, following exposure to desired agonist for 6 hours, endothelial monolayers were incubated for 90 minutes with a mouse monoclonal antibody against PSR $(10 \mu \mathrm{g} / \mathrm{mL}, 200 \mu \mathrm{L} / w e l l)$, an additional 60 minutes with a goat anti-mouse IgM conjugated with alkaline phosphatase (200 $\mu \mathrm{L} /$ well, 1 to 50 dilution), and finally for 15 minutes with the phosphatase substrate Attophos (Promega, Madison, WI). The reaction was terminated by addition of EDTA and product measured fluorometrically (Millipore Cytofluor, Model 2350; Millipore, Bedford, MA) with excitation and emission wavelengths set at $450 \mathrm{~nm}$ and $580 \mathrm{~nm}$, respectively. All conditions were assayed in triplicate, with an intra-assay variability of less than $4 \%$. Background fluorescence was measured with cells subjected to identical treatment in the presence of an isotype-matched negative control antibody. In parallel experiments, VCAM-1, CD36, and VnR, with an appropriate isotype-matched negative control antibody, were evaluated to complement flow cytometric analyses. Surface expression of PSR and other adhesion receptors also were evaluated using HRCECs to complement data from human lung cells.
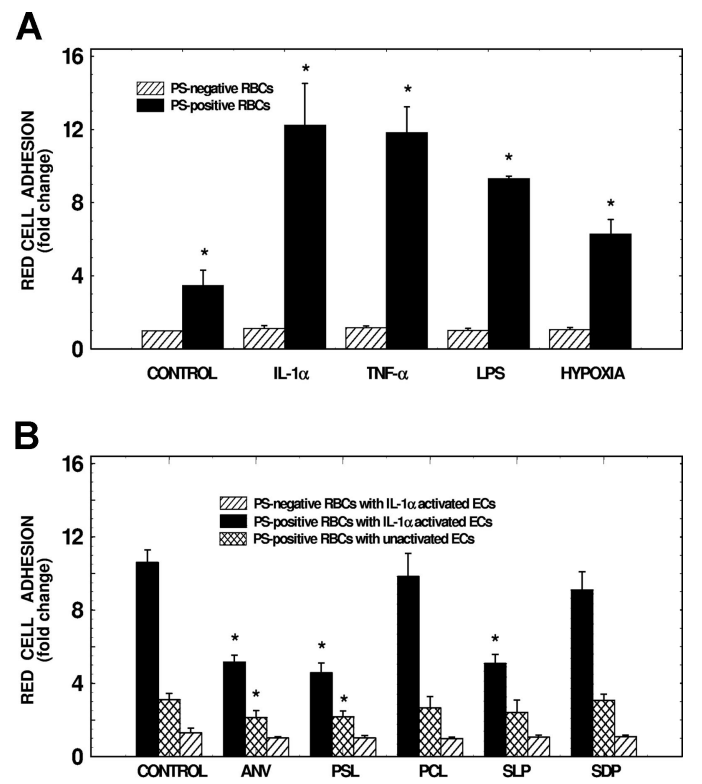

Figure 1. Effects of endothelial activation and modulators of PS interaction on adhesion of PS-positive erythrocytes to human lung microvascular endothelial cells. (A) Effects of endothelial activation on PS-positive erythrocyte adhesion to HLMECs. Endothelial cells were subjected to activation either with hypoxia for 24 hours, or with IL-1 $\alpha(10 \mathrm{ng} / \mathrm{mL})$, TNF- $\alpha(10 \mathrm{ng} / \mathrm{mL})$, or LPS $(100 \mathrm{ng} / \mathrm{mL})$ for 6 hours. Monolayers then were tested for their adhesive potential using either PS-negative or PS-positive red cells prepared by treating control erythrocytes with A23187. Adhesion of red cells to unactivated control endothelium (control) also is shown. Values presented are the mean $( \pm S D$ ) from 3 to 12 experiments. Adhesion of test red cells to test endothelium was presented as fold change compared with adhesion of PS-negative red cells to unactivated endothelial cells. *Values significantly different from the respective controls at $P<.05$ to $P<.001$. (B) Effects of liposomes, serine phosphates, and annexin- $V$ on erythrocyte adhesion to HLMECs. Following activation of endothelial cells for 6 hours with $\mathrm{IL}-1 \alpha(10 \mathrm{ng} / \mathrm{mL})$, cell monolayers were preincubated in the presence or the absence of PC liposomes (PCL), or PS liposomes (PSL) containing $30 \mu \mathrm{M}$ total phospholipid, $100 \mu \mathrm{M}$ serine-L-phosphate (SLP), or $100 \mu \mathrm{M}$ serine-D-phosphate (SDP) for 45 minutes. Monolayers then were tested for their adhesive potential in the presence of appropriate modulator using red cells pretreated for 45 minutes with appropriate inhibitor. In experiments assessing the effects of annexin-V (ANV), PS-positive erythrocytes (used at $2.5 \%$ hematocrit) were pretreated with $300 \mu \mathrm{g}$ annexin- $\mathrm{V} / \mathrm{mL}$ for 45 minutes, and then tested for their adhesive potential. Values presented are the mean $( \pm S D$ ) from 3 to 7 experiments. Adhesion of test red cells to test endothelium was presented as fold change compared with adhesion of PS-negative red cells to unactivated endothelial cells. *Values significantly different from the respective controls at $P<.05$ to $P<.01$.

\section{Statistical analysis}

Statistical evaluation was performed using Sigmastat Statistical Package (Jandel Scientific, San Rafael, CA). All results are presented as means ( $\pm \mathrm{SD}$ ). Multiple group comparison was done using either one-way ANOVA (for data with normal distribution) or the Kruskal-Wallis test (for data with nonnormal distribution). If the $P$ value for this overall comparison was statistically significant at $P<.05$, then group-wise comparison was performed using Dunnett test or Dunn test. The unpaired or paired Student $t$ test, or the Mann-Whitney rank sum test on the medians, if the data showed nonnormal distribution, was used to compare statistical significance between 2 groups.

\section{Results}

Adhesion of PS-positive erythrocytes to lung microendothelial cells under basal and activated conditions

As depicted in Figure 1A, adhesion of PS-positive erythrocytes to lung microendothelial cells increased by approximately 2.5 -fold compared with PS-negative cells $(\mathrm{n}=10, P<.01)$. This adhesion 
A

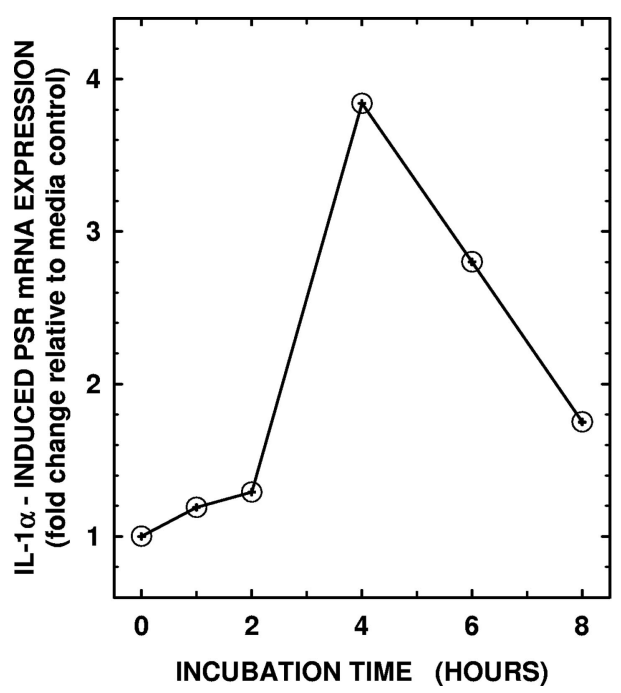

B

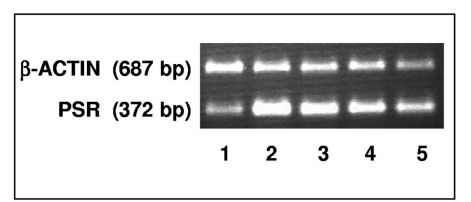

C

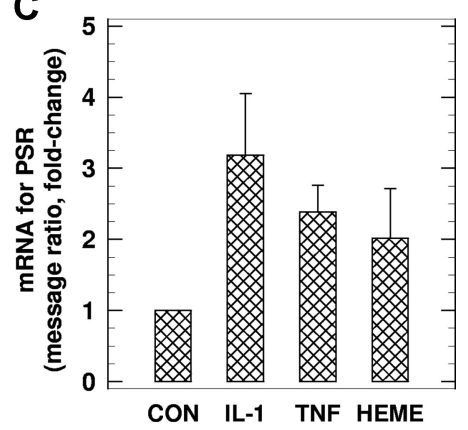

Figure 2. PSR mRNA levels in human lung microendothelial cells. (A) Time-dependent changes in PSR mRNA in HLMECs. Endothelial cells were incubated in the presence of $\mathrm{IL}-1 \alpha$ (10 $\mathrm{ng}$ per $\mathrm{mL}$ ) for times indicated, and total RNA was isolated and analyzed for mRNA for PSR using a semiquantitative RT-PCR assay. (B) Effects of cytokines and heme on PSR mRNA expression in HLMECs. Endothelial cells were incubated for 4 hours in the absence (lane 1) or presence of $10 \mathrm{ng} / \mathrm{mL}$ IL-1 $\alpha$ (lane 2), $10 \mathrm{ng} / \mathrm{mL}$ TNF- $\alpha$ (lane 3), or $100 \mu \mathrm{M}$ heme (lane 4) and then analyzed for PSR mRNA. RT-PCR product of PSR mRNA from unactivated HT1080 cells (used as a positive control for PSR expression) is shown in lane 5 for comparison. $\beta$-Actin mRNA was coamplified with PSR mRNA as an endogenous control for quantitation. The RTPCR products of PSR mRNA (372-bp band) and $\beta$-actin mRNA (687-bp band) from a representative experiment are shown. (C) Densitometric readings of the ratio between PSR and $\beta$-actin messages. Values, presented as fold-change relative to the corresponding media control, are the means $( \pm \mathrm{SD})$ from 3 different experiments. was further enhanced by 2.5- to 8-fold following activation of endothelial cells with agonists such as IL- $1 \alpha$, TNF- $\alpha$, LPS, or hypoxia ( $\mathrm{n}=3$ to $12, P<.05$ to $P<.001$ ). Cell activation had no significant effect on PS-negative erythrocyte adhesion to endothelial cells. As shown in Figure 1B, to assess specificity of PSmediated adhesion, we evaluated the effects of annexin- $\mathrm{V}$ (used to cover surface PS), PS liposomes and serine-L-phosphate (competitors for PS binding), PC liposomes (control for PS liposomes), and serine-D-phosphate (control for serine-L-phosphate) on adhesion. Results demonstrate that preincubation of red cells with annexin- $\mathrm{V}$ or pretreatment of red cells and endothelial cells with PS liposomes inhibited adhesion of PS-positive erythrocytes to activated endothelial cells by $52 \%$ and $57 \%$, respectively $(P<.01)$, while PC liposomes had no effect. While pretreatment of PS-positive red cells and endothelial cells with serine-L-phosphate inhibited erythrocyte adhesion to activated endothelial cells by $52 \%(P<.01)$, serine-D-phosphate had no effect. Adhesion of PS-positive red cells to unactivated endothelial cells also was inhibited by $31 \%$ and $28 \%$ with annexin-V and PS liposomes, respectively $(P<.05)$. None of the PS modulators tested had any significant effect on PS-negative erythrocyte adhesion to activated endothelial cells. These studies demonstrate that the interaction between erythrocytes and endothelial cells is PS specific, and suggest that novel adhesion receptors recognizing PS-positive erythrocytes are expressed on activated endothelium.

\section{Lung microendothelial cells express PSR mRNA and protein}

We next assessed whether PSR (previously reported to be expressed on activated macrophages) was present in endothelial cells. Using RT-PCR, we demonstrate the presence of PSR mRNA in total cellular RNA from unstimulated control human lung microvascular endothelial cells (Figure 2B lane 1). Identity of the PCR product was confirmed by sequence analysis, which showed $100 \%$ homology to this region in the published PSR mRNA sequence. Treatment of endothelial cells with IL- $1 \alpha(10 \mathrm{ng} / \mathrm{mL})$ up-regulated PSR mRNA in a time-dependent manner with maximal levels $(\sim 3$-fold increase) noted at 4 hours following cell activation (Figure 2A,B lane 2, 2C). Activation of endothelial cells with TNF- $\alpha(10 \mathrm{ng} / \mathrm{mL})$ and hemin $(100 \mu \mathrm{M})$ also up-regulated PSR mRNA by $138 \%$ and $100 \%$, respectively (Figure 2B lanes 3,4,2C). We next evaluated whether PSR mRNA was translated to PSR protein in endothelial cells by immunoblotting total cellular proteins with a PSR-specific antibody. Endothelial PSR protein levels mirrored steady-state mRNA levels. Basal PSR protein expression that was detected in unactivated control endothelial cells (Figure 3B lane 1) was up-regulated in a time-dependent manner following activation with IL-1 $\alpha$ with maximal stimulation of approximately $175 \%$ noted over baseline at 6 hours (Figure 3A,B lane 2, 3C). Other activators including TNF- $\alpha$ and hemin, which up-regulated PSR mRNA in endothelial cells, also enhanced PSR protein expression in these cells by $89 \%$ and $58 \%$, respectively, over baseline (Figure 3B lanes 3,4, 3C). These studies demonstrate that lung microendothelial cells express both PSR transcript and protein constitutively, and that their expression is up-regulated by cell activation.
A

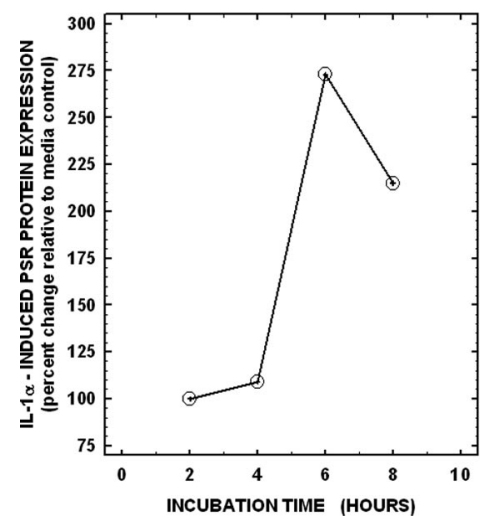

B

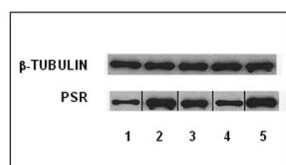

C

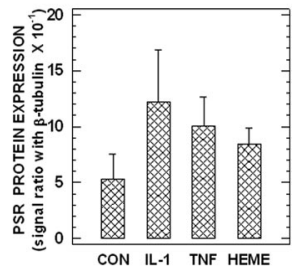

Figure 3. PSR protein expression by human lung microendothelial cells. (A) Time-dependent expression of PSR protein in HLMECs. Endothelial cells were incubated in the presence of IL-1 $\alpha$ (10 $\mathrm{ng}$ per $\mathrm{mL})$ for times indicated, and total proteins were isolated and analyzed for PSR protein using Western blots as described. (B) Effects of cytokines and heme on PSR protein expression in HLMECs. Endothelial cells were incubated for 6 hours in the absence (lane 1) or presence of $10 \mathrm{ng} / \mathrm{mL}$ IL-1 $\alpha$ (lane 2), $10 \mathrm{ng} / \mathrm{mL}$ TNF- $\alpha$ (lane 3), or $100 \mu \mathrm{M}$ heme (lane 4 ) and then analyzed for PSR protein. Total protein extract from unactivated HT1080 cells (used as a positive control for PSR protein expression) is shown in lane 5 for comparison. Equal protein loading was checked by reprobing the stripped immunoblots for $\beta$-tubulin protein. PSR and $\beta$-tubulin protein bands from a representative immunoblasts are shown. Vertical lines between lanes have been inserted to indicate repositioned gel lanes. (C) Densitometric readings of the ratio between PSR and $\beta$-tubulin proteins: Values are the means $( \pm S D)$ from 3 different experiments. 
Unstimulated
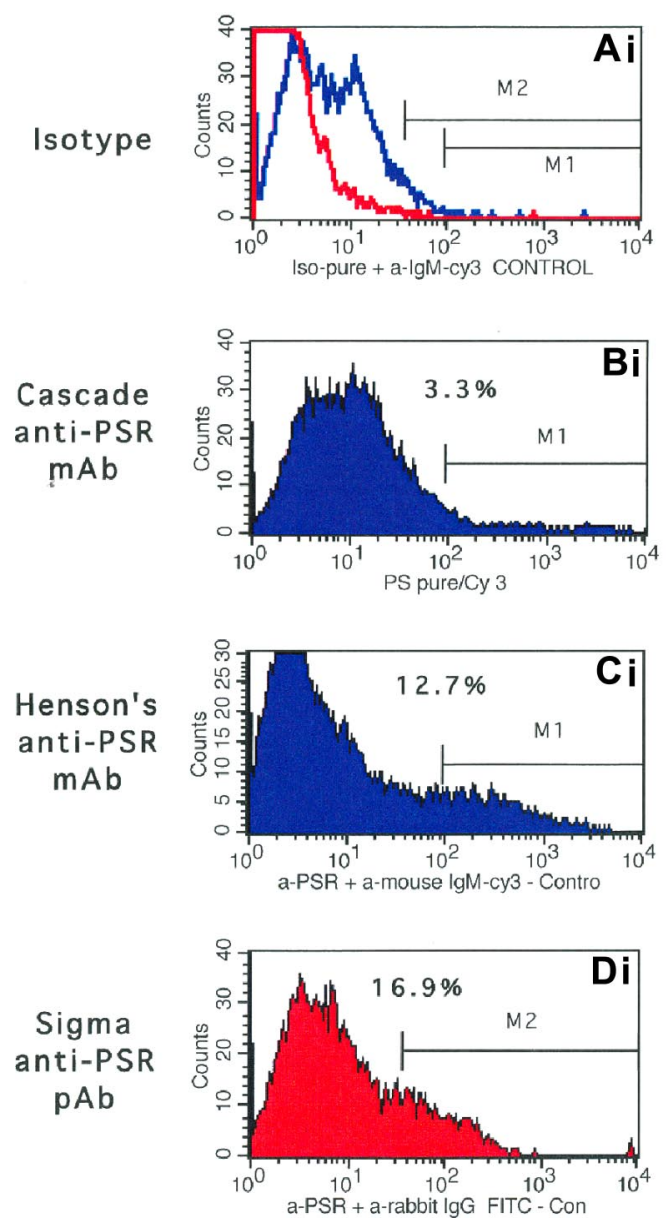

Stimulated with IL-1alpha
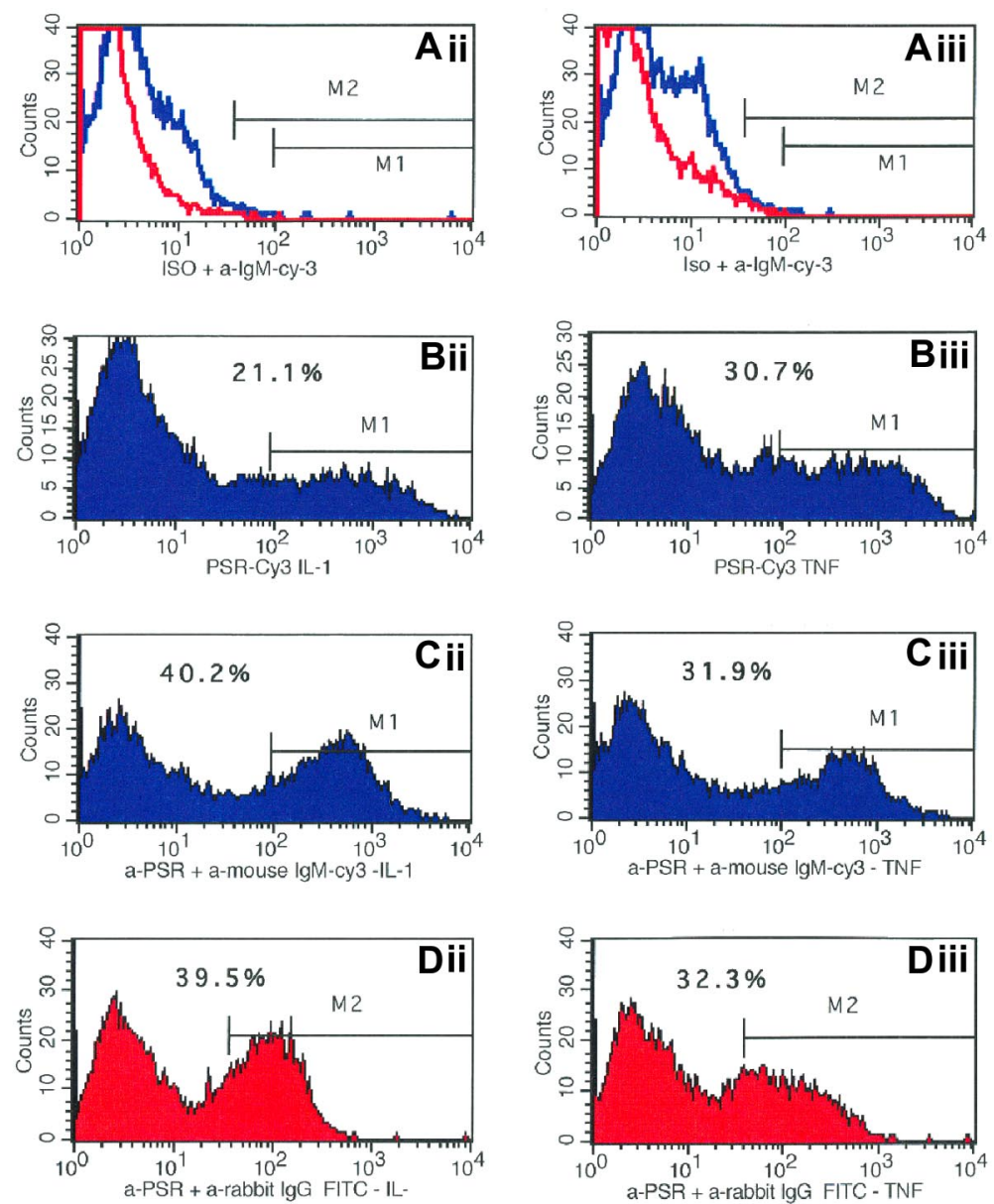

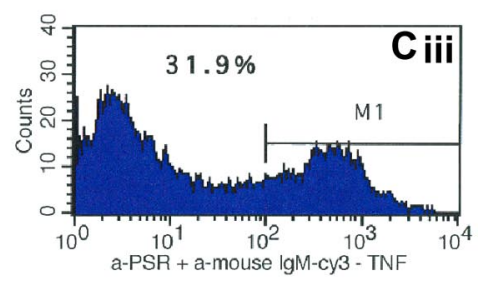

Stimulated with TNF-alpha

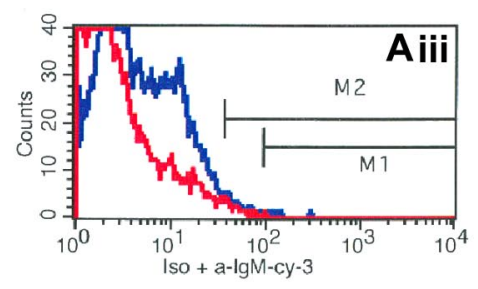

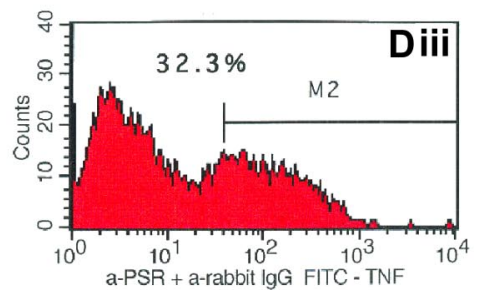

Figure 4. Surface expression of PSR protein on human lung microendothelial cells: analysis by flow cytometry. Following incubation of endothelial cells for 6 hours in the absence (left column) or presence of IL-1 $\alpha$ (10 ng/mL, middle column) or TNF- $\alpha$ (10 ng/mL, right column), cells were harvested, labeled with desired test antibody or an equivalent amount of an isotype-matched negative control, and analyzed by flow cytometry as detailed. Endothelial cells labeled with mouse monoclonal antibody against PSR from Cascade Bioscience (Bi-iii), Dr Henson's laboratories (Ci-iii), and a rabbit polyclonal antibody against PSR from Sigma Chemical (Di-iii) are shown. Results presented are from a representative experiment repeated 4 to 6 times with similar results. Endothelial cells labeled with appropriate isotype-matched negative control antibodies are shown in panels $\mathrm{Ai}$-iii. The red and blue lines are the negative histogram profiles for the rabbit polyclonal and mouse monoclonal antibodies, respectively. Markers $\mathrm{M} 1$ and $\mathrm{M} 2$ are the positive histogram regions for the anti-PSR monoclonal and polyclonal antibodies that were set up with endothelial cells labeled with appropriate isotype-matched negative control antibodies. Percentage marker-positive cells is shown in each panel. HT1080 cells analyzed concomitantly demonstrated $71 \%$ to $79 \%$ positivity with all 3 antibodies.ENDOTHELIAL CELLS AND PHOSPHATIDYLSERINE RECEPTOR 909 BLOOD, 15 JANUARY 2008 • VOLUME 111, NUMBER 2

\section{Cell-surface expression of PSR protein on lung microendothelial cells}

While immunoblotting of total cellular proteins demonstrated the presence of PSR protein in endothelial cells, these experiments did not reveal whether this receptor protein was present on the cell surface. Using complementary flow cytometric- and ELISA-based assays, with IL- $1 \alpha$ and TNF- $\alpha$ as agonists, and both monoclonal (Cascade anti-PSR and Henson antibody) and polyclonal (Sigma Chemical) anti-PSR, we next explored whether PSR protein was expressed on the endothelial surface. Results presented in Figure 4Bi demonstrate that while endothelial cells were minimally positive for PSR in the unactivated state $(3.3 \%$ cells), significant numbers of cells acquired PSR positivity following activation with IL- $1 \alpha$ or TNF- $\alpha(\sim 20 \%$ $30 \%$ cells, Figure 4Bii,iii). Similar PSR expression profiles also were observed when the second mouse monoclonal anti-PSR antibody (Henson antibody, Figure 4Ci-iii) and a PSR polyclonal antibody (Figure 4Di-iii) were used in flow cytometric analysis. These findings also were confirmed using a complemen- tary ELISA-based assay using intact cell monolayer activated with IL- $1 \alpha$ or TNF- $\alpha$ ( $\sim 3$-fold induction with both modulators, Figure 5A). The agonists LPS and hypoxia also induced cell surface PSR expression by 1.6- and 4-fold, respectively (Figure $5 \mathrm{~A})$. Representative adhesion markers that are constitutively expressed (VnR), induced (VCAM-1), and up-regulated (CD36) in endothelial cells also were evaluated concomitantly in both flow cytometric- and ELISA-based analyses for comparison with the PSR expression profile. As shown in Table 1 and Figure $5 \mathrm{~A}$, no significant changes in the constitutively expressing VnR were noted in response to activation by the cytokines IL- $1 \alpha$ or TNF- $\alpha$. While both cytokines induced the expression of VCAM-1 on the lung microendothelium, no significant changes in CD36 expression were noted at the concentration of agonists used in both flow cytometric-based (Table 1) and ELISA-based (Figure 5A) assays. A similar adhesion molecule expression profile was noted in intact human retinal capillary endothelial cell monolayers. These studies demonstrate that while PSR is minimally expressed constitutively on the cell surface, its expression is 
A

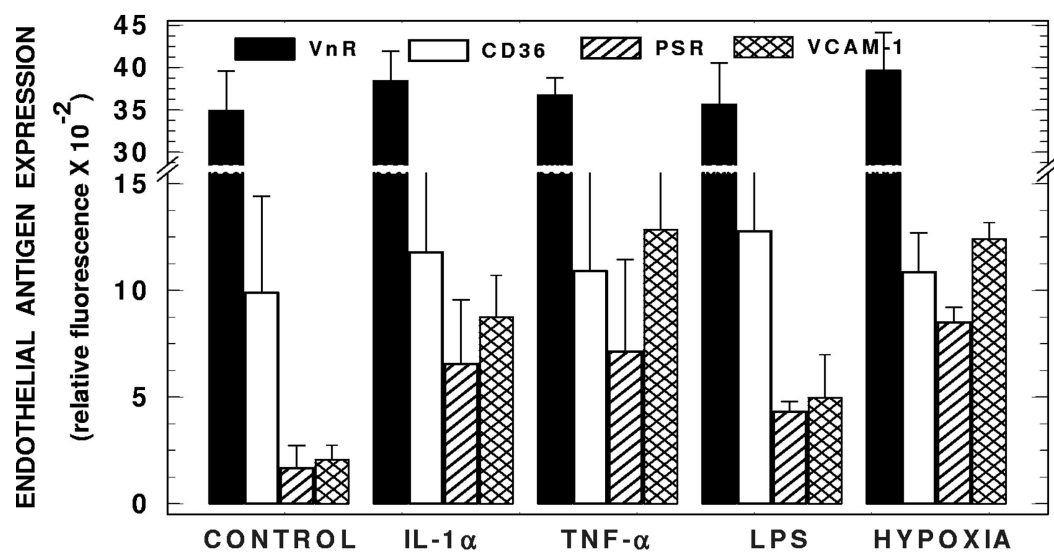

B

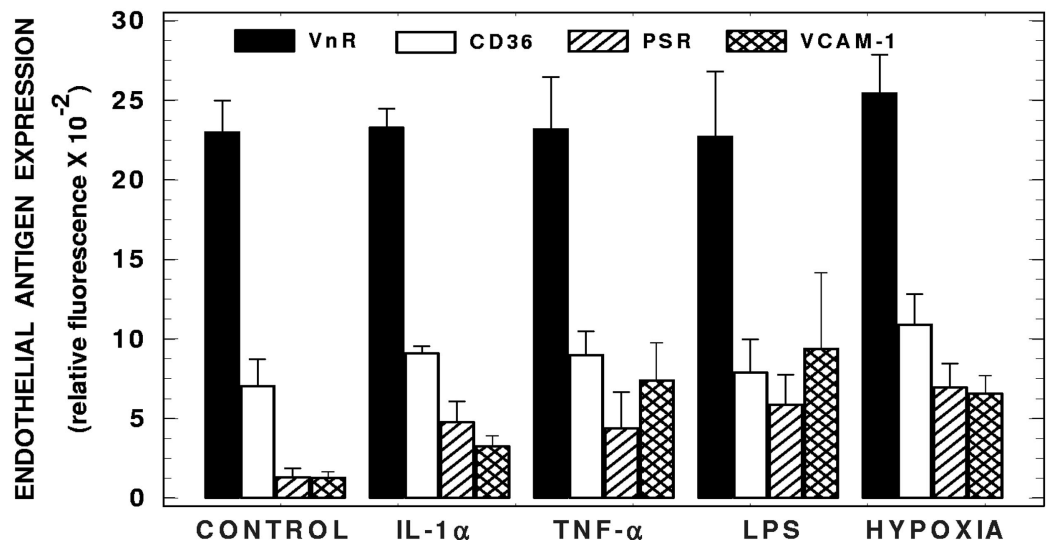

Figure 5. Surface expression of PSR protein and other adhesion markers on human microendothelial cells: analysis by fluorescence ELISA. (A) Expression of PSR protein on intact HLMECs. Human lung microendothelial cells were subjected to activation for 6 hours with IL-1 $\alpha$ (10 ng/mL), TNF- $\alpha$ (10 ng/mL), or LPS (100 ng/mL), or for 24 hours with hypoxia, and then assessed for surface PSR using an ELISA-based assay. Expression profiles of VCAM-1, CD36, and the vitronectin receptor $(\mathrm{VnR})$ in response to endothelial activation are also shown. Values presented are the mean plus or minus SD from 4 to 6 experiments. (B) Expression of PSR protein on intact HRCECs. Human retinal capillary endothelial cells were subjected to activation for 6 hours with IL- $1 \alpha(10 \mathrm{ng} / \mathrm{mL})$, TNF- $\alpha(10 \mathrm{ng} / \mathrm{mL})$, or LPS (100 ng/mL), or for 24 hours with hypoxia, and then assessed for surface PSR using an ELISA-based assay. Expression profiles of VCAM-1, CD36, and the vitronectin receptor $(\mathrm{VnR})$ in response to endothelial activation are also shown. Values presented are the mean plus or minus SD from 3 experiments.
Table 1. Adhesion molecules expressed on human lung microvascular endothelial cells

\begin{tabular}{llcc}
\hline Marker & Unstimulated endothelial & $\begin{array}{c}\text { IL-1 } \boldsymbol{\alpha} \text {-activated } \\
\text { cell control }\end{array}$ & \begin{tabular}{c} 
endothelial cells \\
\hline CD51
\end{tabular} \\
\hline PSR & Positivity & $87 \pm 9 \%$ & $90 \pm 8 \%$ \\
& Positivity & $340 \pm 28$ & $389 \pm 3$ \\
CD36 & MCF & $5 \pm 0.5 \%$ & $26 \pm 3 \%$ \\
& Positivity & $38 \pm 3$ & $175 \pm 21$ \\
ICAM-1 & MCF & $116 \pm 29$ & $30 \pm 16 \%$ \\
& Positivity & $38 \pm 7 \%$ & $115 \pm 43$ \\
VCAM-1 & MCF & $268 \pm 33$ & $92 \pm 3 \%$ \\
& Positivity & $7 \pm 3 \%$ & $607 \pm 9$ \\
${ }^{*} P$-selectin & MCF & $45 \pm 8$ & $53 \pm 16 \%$ \\
& Positivity & Not detected & $322 \pm 97$ \\
& MCF & & Not detected
\end{tabular}

Besides being characterized to be positive for acetylated LDL receptor, Factor VIII-related antigen and CD31 by the manufacturer, the lung endothelial cells used in the study were identified by flow cytometric analyses to be 90 to $98 \%$ positive for constitutively expressing antigens including CD146, and CD144 (two endothelial-specific antigens). Following incubation of endothelial cells for 6 hours in the absence, or presence of IL-1 $\alpha$ $(10 \mathrm{ng} / \mathrm{mL})$, cells were harvested, labeled with desired test antibody or an equivalent amount of an isotype-matched negative control, and analyzed by flow cytometry as detailed. Values presented are the means $( \pm S D)$ from 4 experiments. MCF, mean cell fluorescence, is a measure of receptor density per cell. *While P-selectin expression was undetectable under the experimental conditions described, P-selectin-positivity was noted on endothelial cells activated with A23187 for 30-minutes (see the results section for details). Multiple monoclonal antibodies were employed to identify the expression of ICAM-1 (clones 84H10, and BBIG-I1), VCAM-1 (clones 1G11, 51-10C9, and BBIG-V1), and P-selectin (clones CLB-Thromb/6, and AK-6). Similar expression profiles of adhesion markers were noted on the endothelial surface with different monoclonal antibodies. Results shown for ICAM-1, and VCAM-1 were obtained with clones $84 \mathrm{H} 10$, and 51-10C9, respectively. induced on microendothelial cells following activation with physiologically relevant agonists.

\section{PSR supports adhesion of PS-positive erythrocytes to lung microendothelial cells}

To assess the potential linkage between PSR expression and functional adhesion, we performed concomitant adhesion assays in the presence of PSR-specific antibodies initially using ionophoreactivated HbAA red cells. As depicted in Figure 6, while no significant changes in adhesion to unactivated endothelium was noted, anti-PSR inhibited PS-positive erythrocyte adhesion to activated endothelium by $45 \%(\mathrm{n}=4, P<.01)$. Similar differential inhibitory effects were also observed with the Henson antibody and the polyclonal anti-PSR antibody. Since multiple endothelial receptors support erythrocyte adhesion, it became necessary to identify the adhesion molecules expressed on the surface of the cells that were integral to these experiments (eg, IL- $1 \alpha$-stimulated lung microvascular endothelial cells and the A23187-treated control HbAA erythrocytes). As depicted in Table 1 , IL- $1 \alpha$-activated lung microendothelial cells expressed all adhesion receptors known to interact with red cells with the exception of P-selectin (CD62P). As shown in Table 2, among the red cell adhesion markers evaluated, only PS showed both qualitative and quantitative differences on the ionophore-treated HbAA red cell surface compared with untreated control erythrocytes. In adhesion experiments $(\mathrm{n}=4-6)$, preincubation of endothelial cells with anti-VnR, antiCD36, anti-VCAM-1, anti-ICAM-1, or isotype-matched negative control antibodies (IgG or IgM) had no significant effects on either 


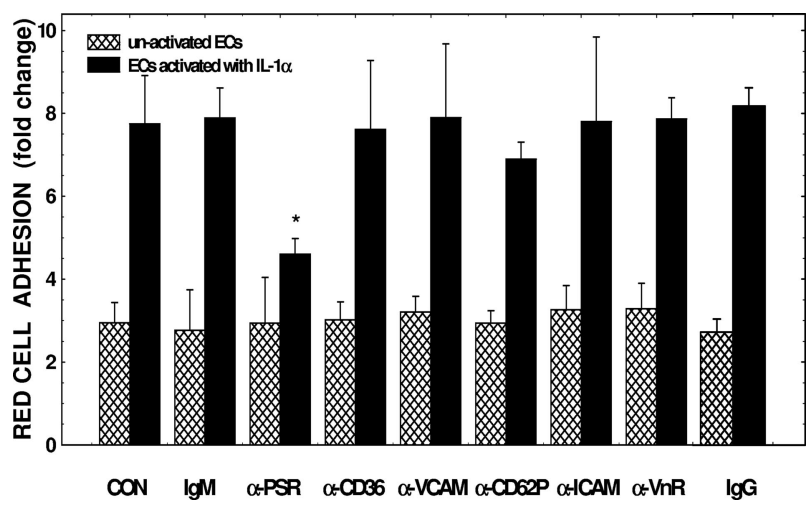

Figure 6. Effects of antibodies against PSR and other endothelial adhesion markers on PS-positive erythrocyte adhesion to human lung microendothelial cells. Following incubation of endothelial cells for 6 hours in the presence or absence of IL-1 $\alpha(10 \mathrm{ng} / \mathrm{mL})$, cell monolayers were pretreated with antibodies against desired adhesion molecule at $40 \mu \mathrm{g} / \mathrm{mL}$, or an equivalent amount of an isotype-matched negative control immunoglobulin (IgG or $\operatorname{lgM}$ ) for 45 minutes. The monolayers were then tested for their adhesive potential using PS-positive red cells with 15\% PS positivity prepared by treating control erythrocytes with A23187. These adhesion assays were performed using red cells at $10 \%$ hematocrit in the absence of plasma and plasma-associated soluble adhesion ligands. Results presented are the mean ( \pm SD) from 3 to 7 experiments. Adhesion of test red cells to test endothelium was presented as fold change compared with adhesion of PS-negative red cells to unactivated endothelial cells. *Values significantly different from the respective medium control or the IgM control at $P<.01$. Please note that to test CD62P or P-selectin-mediated adhesion, endothelial cells were subjected to activation with A23187 for 30 minutes, pretreated with anti-CD62P for 45 minutes, and then assessed for their adhesinogenic potential with PS-positive erythrocytes (see legend to Table 1 and "Results" for additional details).

basal or IL- $1 \alpha$-stimulated adhesion. While CD62P expression was undetectable under the experimental conditions described (ie, IL- $1 \alpha$ activation), P-selectin positivity was noted following endothelial activation with A23187 (160 \pm 140 vs $400 \pm 180$ fluorescence units, $\mathrm{n}=4$, by ELISA with unstimulated and A23187 treated, respectively). To complete these analyses, we therefore pretreated A23187-activated endothelial cells with anti-CD62P, and demonstrate that this antibody had no significant effect on PS-mediated erythrocyte adhesion (Figure 6). In final adhesion experiments, we evaluated erythrocytes from patients with sickle cell disease (HbSS genotype) with various levels of PS positivity ranging from $0.3 \%$ to $11 \%$ dividing them into 2 experimental groups including low versus high PS-positive HbSS erythrocytes $(1.0 \% \pm 0.8 \%$ vs $7.0 \% \pm 2.8 \%$ positivity, $P<.02$, Table 2$)$ as we have done in previous studies. ${ }^{5}$ As shown in Figure 7, while the anti-PSR polyclonal antibody had no significant effect on either unstimulated or IL- $1 \alpha$-stimulated adhesion of low-percentage PS-positive HbSS erythrocytes to microvascular endothelium (panel A), a significant inhibition in adhesion of HbSS erythrocytes containing high-percentage PS-positive cells was noted to IL- $1 \alpha-$ activated microendothelial cells $(65 \% \pm 32 \%$ inhibition of agonistinduced adhesion, $P=.05$, panel B). These findings taken together demonstrate that PSR supports PS-mediated erythrocyte adhesion to IL- $1 \alpha$-activated endothelium in the absence of serum or plasma-associated adhesinogenic ligands and that the adhesion occurs with PS-expressing cells generated under both artificial and pathophysiologic circumstances.

\section{Discussion}

Our results demonstrate that human lung microendothelial cells express both mRNA and protein for PS receptor under basal conditions, and that expression of this receptor is up-regulated following endothelial activation. While minimally expressed on the cell surface under basal conditions, surface expression of PSR is up-regulated following cell activation by a variety of pathophysiologic agonists including IL- $1 \alpha$, TNF- $\alpha$, LPS, heme, and hypoxia. In additional experiments, we demonstrate that PSR expressed on the cell surface is functional, supporting the direct adhesion of PS-positive erythrocytes to activated microendothelium.

PSR, originally described by Fadok et al, is expressed on the surface of activated macrophages, ${ }^{12}$ and also present constitutively on the surface of fibroblasts and epithelial cells, ${ }^{12}$ with recent studies also documenting nuclear localization in fibroblasts. ${ }^{24}$ It is not expressed by the circulating cellular elements of blood including neutrophils, lymphocytes, monocytes, and erythrocytes. ${ }^{12}$ PSR, expressed on both phagocytes (macrophages) and nonphagocytes (fibroblasts and epithelial cells), appears to mediate phagocytic recognition and removal of PS-expressing apoptotic cells, ${ }^{12,20,21,25}$ although there remains some controversial evidence regarding this function. PSR plays an essential role in development and differentiation of multiple organs during embryogenesis. Using PSR knockout mouse models, recent studies have demonstrated that PSR disruption leads to growth retardation and defects in embryonic organogenesis and perinatal lethality presumed to be due to ineffective apoptotic cell phagocytosis, although this has

Table 2. Adhesion molecules expressed on control erythrocytes made artificially PS-positive and on erythrocytes from patients with sickle cell disease

\begin{tabular}{|c|c|c|c|c|c|}
\hline \multirow[b]{2}{*}{ Marker } & & \multicolumn{2}{|c|}{ Erythrocytes from control donors } & \multicolumn{2}{|c|}{ Erythrocytes from patients with sickle cell disease } \\
\hline & & Untreated $(n=4)$ & $\begin{array}{l}\text { *A23187-treated erythrocytes } \\
\text { diluted with untreated RBCs }(n=4)\end{array}$ & †Low PS group $(n=4)$ & †High PS group $(n=5)$ \\
\hline CD36 & Positivity & Not present & Not present & $0.5 \pm 0.5 \%$ & $1.4 \pm 1.7 \%$ \\
\hline VLA4 & Positivity & Not present & Not present & $0.03 \pm 0.06 \%$ & $0.03 \pm 0.06 \%$ \\
\hline PS & Positivity & $<0.3 \%$ & $15 \%$ & $1.0 \pm 0.8 \%$ & $\dagger+7.0 \pm 2.8 \%$ \\
\hline CD47 (IAP) & Positivity; MCF & $100 \% ; 629 \pm 15$ & $100 \% ; 630 \pm 5$ & $99 \pm 1 \% ; 698 \pm 52$ & $99 \pm 1 \% ; 721 \pm 41$ \\
\hline CD239 (BCAM/LU) & Positivity; MCF & $23 \pm 16 \% ; 305 \pm 47$ & $20 \pm 13 \% ; 300 \pm 32$ & $44 \pm 9 \% ; 414 \pm 12$ & $21 \pm 16 \% ; 389 \pm 79$ \\
\hline
\end{tabular}

Cell-surface PS and other potential erythrocyte adhesion markers were evaluated using 2-color flow cytometry and employing anti-glycophorin A as a marker for red cells. Values presented are the mean $( \pm \mathrm{SD}$ ). Mean cell fluorescence (MCF) is a measure of receptor density per cell. Changes (positivity or MCF) noted with CD47 or CD239 between the control and A23187-treated erythrocyte were not significantly different from each other. The "low" PS sickle cell group is compared with the "high" PS sickle cell group to demonstrate that the adhesion marker differences between these two HbSS groups was confined to significant differences in PS positivity.

IAP indicates integrin associated protein; and BCAM/LU, basal cell adhesion molecule/Lutheran protein.

${ }^{*}$ PS-positive red cells were prepared by treating control HbAA erythrocytes with A23187 and diluted with untreated red cells to obtain a cell suspension containing $15 \%$ PS positivity.

†Erythrocytes from patients with sickle cell disease (HbSS genotype) were divided into 2 experimental groups including low PS and high PS groups based on percent PS positivity as in our previous study. ${ }^{5}$

$\dagger † P<.02$ compared to low PS group. 
A

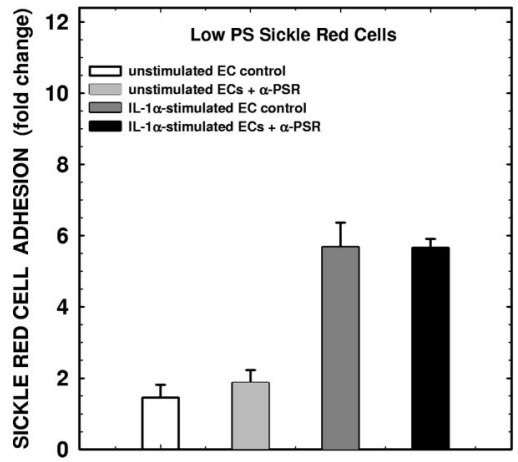

B

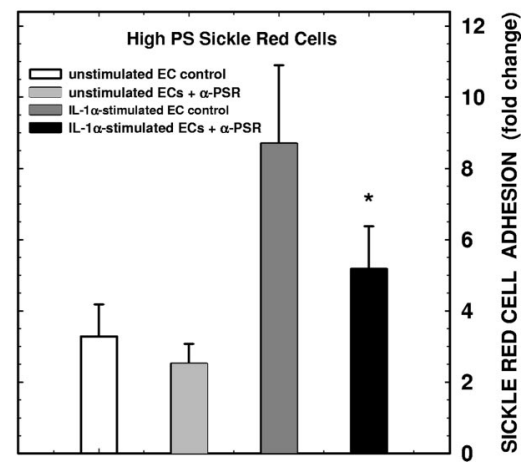

Figure 7. Effects of rabbit polyclonal antibody against PSR on sickle erythrocyte adhesion to human lung microendothelial cells. Following incubation of endothelial cells for 6 hours in the presence or absence of IL-1 $\alpha(10 \mathrm{ng} / \mathrm{mL})$, cell monolayers were pretreated with rabbit polyclonal antibody against PSR (at $20 \mu \mathrm{g} / \mathrm{mL}$ ) for 30 minutes. The monolayers were then tested for their adhesive potential using red cells from patients with sickle cell disease (HbSS genotype). Adhesion assays were performed using red cells at $10 \%$ hematocrit in the absence of plasma and plasma-associated soluble adhesion ligands. Panels A and B represent adhesion of $\mathrm{HbSS}$ erythrocytes with low PS positivity $(1.0 \% \pm 0.8 \%$ positivity) and high PS positivity $(7.0 \% \pm 2.8 \%$ positivity), respectively. Results presented are the mean ( $\pm \mathrm{SD}$ ) from 4 (A) or 5 (B) experiments. Adhesion of sickle red cells to test endothelium was presented as fold change compared with adhesion of control red cells to unactivated endothelial cells. ${ }^{\star} P=.05$ compared with the IL- $1 \alpha$ control. been recently questioned. ${ }^{26-29}$ PSR appears to be a glycosylated protein with an apparent molecular size of $70 \mathrm{kDa}^{12}$ and contains a type II transmembrane domain, a potential intracellular tyrosine phosphorylation site, and an extracellular domain containing runs of serines (which could be involved in protein O-glycosylation) and runs of basic amino acids lysine and arginine that could provide potential binding sites for the anionic phospholipid PS. ${ }^{12}$ While recent studies have also identified multiple nuclear localization signals in the PSR sequence, ${ }^{24}$ a physiologic role for nuclear PSR has yet to be elucidated. In the present study, we found that the endothelial PSR migrated as a protein with a molecular size of approximately $70 \mathrm{kDa}$. While we observed both basal and upregulated expression of endothelial PSR, surface expression was noted mainly on activated endothelium using both polyclonal and monoclonal antibodies. A recent study also documented constitutive expression of PSR in a macrovascular endothelium, ${ }^{22}$ and showed that PSR mediated tethering of apoptotic Jurkat cells to endothelial cells. ${ }^{22}$ In the present study, we have characterized PSR expression at both mRNA and protein level in pathologically relevant human pulmonary microvascular endothelium. We have also used complementary methods (Western blotting, flow cytometry, and ELISA assays) and also both polyclonal and monoclonal antibodies to characterize PSR protein. In addition, we have demonstrated that endothelial activation by IL- $1 \alpha$, TNF- $\alpha$, LPS, heme, and hypoxia up-regulated surface expression of PSR.

The findings that surface PSR expression occurred mainly on the activated endothelium and that pretreatment of activated endothelial cells with anti-PSR antibody inhibited adhesion of PS-positive erythrocytes in the absence of plasma or soluble plasma adhesion ligands demonstrate that endothelial PSR supports PS-mediated direct interaction of erythrocytes to activated microendothelium. PSR is very unlikely to be involved under basal unstimulated conditions since PSR does not appear to be constitutively expressed on the cell surface, with the antibody-blocking experiments corroborating the null effect. These results also implicate at least one more additional non-PSR-associated pathway by which PS-positive cells interact directly with activated endothelial cells in the absence of plasma ligands. Existence of a non-PSR-mediated adhesion pathway was also suggested by the findings that PS-positive erythrocytes interacted with unactivated control endothelial cells and that this basal adhesion was not affected by pretreatment of endothelial cells with anti-PSR prior to adhesion. Since previous studies demonstrated that erythrocytes from pathologic milieu interact, either directly or indirectly via plasma ligands, with CD $36,{ }^{30} \mathrm{VnR},{ }^{30,31} \mathrm{VCAM}-1,{ }^{32} \mathrm{ICAM}-1,{ }^{33}$ and P-selectin $^{34}$ (also reviewed in references Frenette ${ }^{35}$; Parise and
Telen ${ }^{36}$; Stuart and $\mathrm{Nagel}^{37}$ ), and since human lung microendothelial cells express these adhesion molecules either constitutively or following activation (Table 1), we explored the possible involvement of these receptors in the direct adhesion of PS-positive erythrocytes to human lung microendothelial cells. Antibodyblocking studies (Figure 6) suggested that these latter endothelial receptors are not involved. In our adhesion experiments, we initially used PS-positive erythrocytes prepared by activating control HbAA erythrocytes with the calcium ionophore A23187. Use of HbAA control cells obviated the involvement of the adhesion markers VLA4 and CD36 that are also expressed with PS on a subset of young erythrocytes (stress reticulocytes) in patients with hemolytic anemias including sickle cell disease. ${ }^{5,32,38-40}$ While other adhesion molecules including CD47 and B-CAM/LU are also present on control erythrocytes, ${ }^{41,42}$ levels (both receptor positivity and density) of these receptors did not change following activation of red cells with the ionophore. Erythrocyte-endothelial interactions described in this study appeared to be mediated, in part, via erythrocyte PS, since pretreatment of PS-positive erythrocytes with annexin-V, or preincubation of erythrocytes and/or endothelial cells with PS liposomes, or serine-L-phosphate inhibited adhesion (Figure 1B). In contrast, PC liposomes and serine-D-phosphate had no effect on this process.

Erythrocytes from patients with several hemolytic anemias including sickle cell disease (SCD), ${ }^{3-5}$ thalassemia, ${ }^{6}$ malaria, ${ }^{7}$ and chronic renal failure ${ }^{8,9}$ are positive for PS with levels ranging from $0.5 \%$ to more than $10 \%$, and exhibit increased adhesiveness to endothelium, with our previous published data documenting a significant positive correlation between percentage sickle red cell PS positivity and adhesion where enhanced erythrocyte-endothelial adhesion was noted in the high PS-positive group (mean percentage positivity at $5.6 \%) .{ }^{5}$ In the present in vitro study, we also note that PS-mediated erythrocyte adhesion occurs at similar levels of PS positivity (mean percentage positivity at 7\%), and that a polyclonal antibody against PSR significantly inhibited this adhesion (Figure 7). Erythrocyte adhesion to endothelium correlates with disease severity in patients with $\mathrm{SCD},{ }^{18}$ and is a major etiologic factor in the pathogenesis of the vaso-occlusive or painful crisis with long-term effects including chronic organ dysfunction leading to increased morbidity and mortality. ${ }^{37,43}$ Cell-surface expression of PSR occurred on the microendothelium following activation of cells in vitro with agonists such as IL- $1 \alpha, \mathrm{TNF}-\alpha$, heme, and hypoxia, agonists that are all pathologically relevant in patients with sickle cell disease. ${ }^{44-48}$ Evidence also suggests both chronic and acute endothelial activation in these patients as documented by elevated levels of soluble VCAM-1, E-selectin, and 
ICAM-1 by many investigators including results from our laboratories. ${ }^{49-53}$ It is not known whether in vivo PSR expression occurs under the influence of agonists that caused PSR expression under the in vitro conditions described here, and whether red cell PS-endothelial PSR adhesion occurs in the microvasculature in such pathologic conditions as SCD and malarial infection where such adhesion could influence disease pathology. Further studies are required in appropriate animal models such as the transgenic sickle mouse to delineate further the relevance of this novel endothelial receptor in the process of in vivo cell-cell adhesion.

An interesting observation made by several investigators related to PSR is its involvement in mediating anti-inflammatory responses in numerous experimental models. ${ }^{12,23,25}$ Ligation of PSR with apoptotic cells through PS or PS liposomes up-regulated the production of anti-inflammatory cytokines transforming growth factor- $\beta$ and IL-10 concomitant with the down-regulation of the proinflammatory cytokines TNF- $\alpha$ and IL-1 in mouse macrophages $^{12}$ and epithelial cells. ${ }^{25}$ Endothelial cells appear to synthesize and release many proinflammatory and anti-inflammatory cytokines including IL-1, IL-6, IL-8, and ET-1. ${ }^{54,55}$ Thus, an additional role for endothelial PSR in the microvasculature could be the modulation of the inflammatory phenotype especially in disease states where the combination of adhesion and inflammation are a particularly potent mix in relation to vascular and organ dysfunction. ${ }^{48,56-58}$

In summary, we demonstrated the presence of a receptor for phosphatidylserine, PSR, on the surface of human microendothelial cells using both antigen expression and mRNA analysis. While PSR is not constitutively expressed, its expression can be induced on the surface of microendothelium by relevant agonists such as LPS, cytokines, hypoxia, and heme. PSR is involved in mediating direct interaction of PS-positive erythrocytes with microendothe- lial cells. The in vivo significance of these interactions requires further studies in relevant disease models.

\section{Acknowledgments}

B.N.Y.S. thanks Dr Marie Stuart for her support throughout the study, critical evaluation of the study design, and review of the paper. We thank Dr Saul Surrey for his evaluation of the paper, Dr Peter Henson for the kind gift of anti-PSR antibody and his review of our paper, Mrs Surekha Kulkarni and Dottie Shields for their assistance in data acquisition in some flow cytometry-related experiments, and Mrs Jie Zhang for assistance in setting up Western analysis. The authors also thank Dr Carlton Dampier and the staff members of the division of Hematology, St Christopher's Hospital for Children, Drexel University, for their cooperation in obtaining blood samples for these studies.

This work was supported by grants U54 HL70585 and R01 HL73944 from the National Heart, Lung and Blood Institute, National Institutes of Health, Bethesda, MD.

\section{Authorship}

Contribution: B.N.Y.S. designed the study, supervised and performed the experiments, performed statistical analysis, critically evaluated and interpreted the data, and wrote the paper. S.G.B. performed molecular biology experiments.

Conflict-of-interest disclosure: The authors declare no competing financial interests.

Correspondence: B. N. Yamaja Setty, Thomas Jefferson University, Department of Pediatrics, Medical College Bldg, Suite 727, 1025 Walnut St, Philadelphia, PA 19107; e-mail: yamaja.setty@ jefferson.edu.

\section{References}

1. Zwaal RFA, Comfurius P, Bevers EM. Surface exposure of phosphatidylserine in pathological cells. Cell Mol Life Sci. 2005;62:971-988.

2. Kuypers FA. Phospholipid asymmetry in health and disease. Current Opin Hematol. 1998;5:122131.

3. Kuypers FA, Lewis RA, Hua M, et al. Detection of altered membrane phospholipids asymmetry in subpopulations of human red blood cells using fluorescently labeled annexin V. Blood. 1996;87: 1179-1187.

4. Wood BL, Gibson DF, Tait JF. Increased erythrocyte phosphatidylserine exposure in sickle cell disease: flow-cytometric measurement and clinical associations. Blood. 1996;88:1873-1880.

5. Setty BNY, Kulkarni S, Stuart MJ. Role of erythrocyte phosphatidylserine in sickle red cell-endothelial adhesion. Blood. 2002;99:1564-1571.

6. Kuypers FA, Yuan J, Lewis RA, et al. Membrane phospholipid asymmetry in human thalassemia. Blood. 1998;91:3044-3051.

7. Eda S, Sherman IW. Cytoadherence of malariainfected red blood cells involves exposure of phosphatidylserine. Cell Physiol Biochem. 2002; 12:373-384.

8. Bonomini M, Sirolli V, Settefrati N, et al. Increased erythrocyte phosphatidylserine exposure in chronic renal failure. J Am Soc Nephrol. 1999;10: 1982-1990.

9. Bonomini M, Sirolli V, Gizzi F, et al. Enhanced adherence of human uremic erythrocytes to vascular endothelium: role of phosphatidylserine exposure. Kidney Intl. 2002;62:1358-1363.

10. Manodori AB, Barabino GA, Lubin BH, Kuypers FA. Adherence of phosphatidylserine-exposing erythrocytes to endothelial matrix thrombospondin. Blood. 2000;95:1293-1300.

11. Closse C, Dachary-Prigent J, Boisseau MR, et al Phosphatidylserine-related adhesion of human erythrocytes to vascular endothelium. $\mathrm{Br} \mathrm{J}$ Haematol. 1999;107:300-302.

12. Fadok VA, Bratton DL, Rose DM, et al. A receptor for phosphatidylserine-specific clearance of apoptotic cells. Nature. 2000;405:85-90.

13. Setty BNY, Dampier CD, Stuart MJ. Arachidonic acid metabolites are involved in mediating red blood cell adherence to endothelium. J Lab Clin Med. 1995;125:608-617.

14. Setty BNY, Rao AK, Stuart MJ. Thrombophilia in sickle cell disease: the red cell connection. Blood. 2001;98:3228-3233.

15. Setty BNY, Kulkarni S, Dampier CD, Stuart MJ. Fetal hemoglobin in sickle cell anemia: relationship to erythrocyte adhesion markers and adhesion. Blood. 2001;97:2568-2573.

16. Del Vecchio PJ, Sharuk GS, MacElroy KS. Isolation and culture of cells from human retinal microvessels. Invest Ophthalmol Vis Sci. 1984;25S: 247.

17. Fadok VA, Voelker DR, Campbell PA, et al. Exposure of phosphatidylserine on the surface of apoptotic lymphocytes triggers specific recognition and removal by macrophages. J Immunol. 1992; 148:2207-2216.

18. Hebbel RP, Boogaerts MA, Eaton JW, Steinberg $\mathrm{MH}$. Erythrocyte adherence to endothelium in sickle-cell anemia: a possible determinant of disease severity. N Engl J Med. 1980;302:992-995.

19. Setty BNY, Stuart MJ. Vascular cell adhesion molecule-1 is involved in mediating hypoxia-induced sickle red blood cell adherence to endothelium: potential role in sickle cell disease. Blood. 1996; 88:2311-2320.

20. Sexton DW, Blaylock MG, Walsh GM. Human alveolar epithelial cells engulf apoptotic eosinophils by means of integrin- and phosphatidylserine receptor-dependent mechanisms: a process upregulated by dexamethasone. J Allergy Clin Immunol. 2001;108:962-969.

21. Cao WM, Murao K, Imachi H, et al. Phosphatidylserine receptor cooperates with high-density lipoprotein receptor in recognition of apoptotic cells by thymic nurse cells. J Mol Endocrinol. 2004;32:497-505.

22. Arur S, Uche UE, Rezaul K, et al. Annexin I is an endogenous ligand that mediates apoptotic cell engulfment. Dev Cell. 2003;4:587-598.

23. DeSimone R, Ajmone-Cat MA, Nicolini A, Minghetti L. Expression of phosphatidylserine receptor and down-regulation of pro-inflammatory molecule production by its natural ligand in rat microglial cultures. J Neuropathol Exptl Neurol. 2002; 61:237-244.

24. Cui P, Qin B, Liu N, et al. Nuclear localization of the phosphatidylserine receptor protein via multiple nuclear localization signals. Experimental Cell Res. 2004;293:154-163.

25. Monks J, Rosner D, Geske FJ, et al. Epithelial cells as phagocytes: apoptotic epithelial cells are engulfed by mammary alveolar epithelial cells and repress inflammatory mediator release. Cell Death Diff. 2005;12:107-114.

26. Li MO, Sarkisian MR, Mehal WZ, et al. Phosphatidylserine receptor is required for clearance of apoptotic cells. Science. 2003;302:1560-1563. 
27. Kunisaki Y, Masuko S, Noda M, et al. Defective fetal liver erythropoiesis and T lymphopoiesis in mice lacking the phosphatidylserine receptor. Blood. 2004;103:3362-3364.

28. Bose J, Gruber AD, Helming L, et al. The phosphatidylserine receptor has essential functions during embryogenesis but not in apoptotic cell removal. J Boil. 2004;3:15.1-15.18.

29. Mitchell JE, Cvetanovic M, Tibrewal N, et al. The presumptive phosphatidylserine receptor is dispensable for innate anti-inflammatory recognition and clearance of apoptotic cells. J Biol Chem. 2006;281:5718-5725.

30. Brittain HA, Eckman JR, Howard RJ, Wick TM. Thrombospondin from activated platelets promotes sickle erythrocyte adherence to human microvascular endothelium under physiologic flow: a potential role for platelet activation in sickle cell vaso-occlusion. Blood. 1993;81:21372143.

31. Kaul DK, Tsai HM, Liu XD, et al. Monoclonal antibodies to $\alpha$ V $\beta 3$ (7E3 and LM609) inhibit sickle red blood cell-endothelium interactions induced by platelet-activating factor. Blood. 2000;95:368374.

32. Swerlick RA, Eckman JR, Kumar A, et al. Alpha 4 beta 1-integrin expression on sickle reticulocytes: vascular cell adhesion molecule-1-dependent binding to endothelium. Blood. 1993;82:18911899

33. Ockenhouse CF, Betageri R, Springer TA, Staunton DE. Plasmodium falciparum-infected erythrocytes bind ICAM-1 at a site distinct from LFA-1, Mac-1, and human rhinovirus. Cell. 1992;68:6369.

34. Matsui NM, Borsig L, Rosen SD, et al. P-selectin mediates the adhesion of sickle erythrocytes to the endothelium. Blood. 2001;98:1955-1962.

35. Frenette PS. Sickle cell vaso-occlusion: multistep and multicellular paradigm. Curr Opin Hematol. 2002:9:101-106.

36. Parise LV, Telen MJ. Erythrocyte adhesion in sickle cell disease. Curr Hematol Reports. 2003; 2:102-108.
37. Stuart MJ, Nagel RL. Sickle-cell disease. Lancet. 2004;364:1343-1360

38. Sugihara K, Sugihara T, Mohandas N, Hebbel RP. Thrombospondin mediates adherence of CD36 ${ }^{+}$ sickle reticulocytes to endothelial cells. Blood. 1992;80:2634-2642.

39. Joneckis CC, Ackley RL, Orringer EP, et al. Integrin alpha 4 beta 1 and glycoprotein IV (CD36) are expressed on circulating endothelial reticulocytes in sickle cell anemia. Blood. 1993;82:35483555.

40. de Jong K, Larkin SK, Styles LA, et al. Characterization of the phosphatidylserine-exposing subpopulation of sickle cells. Blood. 2001;98:860867.

41. Brittain JE, Milnar KJ, Anderson CS, et al. Integrin-associated protein is an adhesion recepto on sickle red blood cells for immobilized thrombospondin. Blood. 2001;97:2159-2164.

42. Udani M, Zen Q, Cottman M, et al. Basal cell adhesion molecule/Lutheran protein. The receptor critical for sickle cell adhesion to laminin. J Clin Invest. 1998;101:2550-2558.

43. Platt OS, Brambilla DJ, Rosse WF, et al. Mortality in sickle cell disease: life expectancy and risk factors for early death. N Eng J Med. 1994;330: 1639-1644.

44. Francis RB Jr, Haywood LJ. Elevated immunoreactive tumor necrosis factor and interleukin-1 in sickle cell disease. J Natl Med Assoc. 1992;84: 611-615.

45. Malave I, Perdomo Y, Escalona E, et al. Levels of tumor necrosis factor alpha/cachectin (TNF alpha) in sera from patients with sickle cell disease. Acta Haematologia. 1993;90:172-176.

46. Reiter CD, Wang X, Tanus-Santos JE, et al. Cellfree hemoglobin limits nitric oxide bioavailability in sickle-cell disease. Nat Med. 2002;8:1383 1389.

47. Rother RP, Bell L, Hillmen P, Gladwin MT. The clinical sequelae of intravascular hemolysis and extracellular plasma hemoglobin: a novel mechanism of human disease. JAMA. 2005;293:16531662.
48. Hebbel RP, Osarogiagbon R, Kaul D. The endothelial biology of sickle cell disease: inflammation and a chronic vasculopathy. Microcirculation. 2004;11:129-151.

49. Stuart MJ, Setty BN. Sickle cell acute chest syndrome: pathogenesis and rationale for treatment Blood. 1999;94:1555-1560.

50. Setty BN, Stuart MJ, Dampier CD, et al. Hypoxaemia in sickle cell disease: biomarker modulation and relevance to pathophysiology. Lancet. 2003;362:1450-1455.

51. Duits AJ, Pieters RC, Saleh AW, et al. Enhanced levels of soluble VCAM-1 in sickle cell patients and their specific increment during vasoocclusive crisis. Clin Immunol Immunopathol. 1996;81:9698.

52. Conran N, Fattori A, Saad ST, Costa FF. Increased levels of soluble ICAM-1 in the plasma of sickle cell patients are reversed by hydroxyurea. Am J Hematol. 2004;76:343-347.

53. Mohan JS, Lip GYH, Wright J, et al. Plasma levels of tissue factor and soluble E-selectin in sickle cell disease: relationship to genotype and to inflammation. Blood Coagul Fibrinolysis. 2005;16: 209-214.

54. Wei L, Harmon DC, Wang JH, et al. Activated endothelial interleukin- $1 \beta,-6$, and -8 concentrations and intercellular adhesion molecule-1 expression are attenuated by Lidocaine. Anesth Analg. 2005; 100:409-412.

55. Pober JS, Cotran RS. Cytokines and endothelia cell biology. Physiol Rev. 1990;70:427-451.

56. Platt OS. Sickle cell anemia as an inflammatory disease. J Clin Invest. 2000;106:337-338.

57. Savoia C, Schiffrin EL. Vascular inflammation in hypertension and diabetes: molecular mechanisms and therapeutic interventions. Clin Sci. 2007;112:375-384.

58. Clark IA, Budd AC, Alleva LM, Cowden WB. Human malarial disease: a consequence of inflammatory cytokine release. Malarial J. 2006;5:85:1 32 